See discussions, stats, and author profiles for this publication at: https://www.researchgate.net/publication/337107382

\title{
Scavenger communities and fisheries waste: North Sea discards support 3 million seabirds, 2 million fewer than in 1990
}

Article in Fish and Fisheries · November 2019

DOI: 10.1111/faf.12422

\section{CITATIONS}

5 authors, including:

Richard B Sherley

University of Exeter

72 PUBLICATIONS 506 CITATIONS

SEE PROFILE

Stefan Garthe

Christian-Albrechts-Universität zu Kiel

246 PUBLICATIONS 5,598 CITATIONS

SEE PROFILE
READS

46

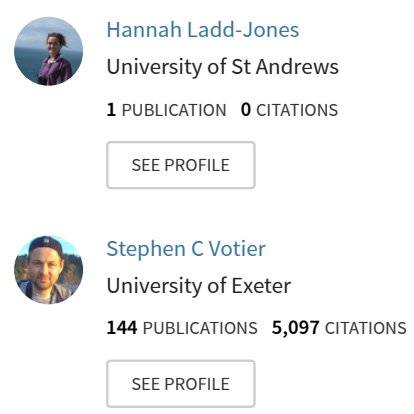

Some of the authors of this publication are also working on these related projects:

Project $\quad$ Recovery of Eurasian Crane in Great Britain View project

Project The impact of recent and future climate changes and Human pressures on marine biodiversity View project 


\title{
Scavenger communities and fisheries waste: North Sea discards support 3 million seabirds, 2 million fewer than in 1990
}

\author{
Richard B. Sherley $^{1}$ (D) | Hannah Ladd-Jones ${ }^{1}$ | Stefan Garthe ${ }^{2}$ | Olivia Stevenson ${ }^{1}$ | \\ Stephen C. Votier ${ }^{1}$
}

\author{
${ }^{1}$ Environment and Sustainability \\ Institute/Centre for Ecology \& \\ Conservation, University of Exeter, Penryn, \\ UK \\ ${ }^{2}$ Research and Technology Centre \\ (FTZ), University of Kiel, Büsum, Germany
}

\section{Correspondence}

Richard B. Sherley and Stephen C. Votier, Environment and Sustainability Institute, University of Exeter, Penryn Campus, Penryn, TR10 9FE, UK.

Email:r.sherley@exeter.ac.uk; s.c.votier@ exeter.ac.uk

Funding information Leiden Conservation Foundation; Bristol Zoological Society; Zoological Society of San Diego; Pew Charitable Trusts

\begin{abstract}
Every year fisheries discard $>10$ million tonnes of fish. This provides a bounty for scavengers, yet the ecological impact of discarding is understudied. Seabirds are the best-studied discard scavengers and fisheries have shaped their movement ecology, demography and community structure. However, we know little about the number of scavenging seabirds that discards support, how this varies over time or might change as stocks and policy change. Here, we use a Bayesian bioenergetics model to estimate the number of scavenging birds potentially supported by discards in the North Sea (one of the highest discard-producing regions) in 1990, around the peak of production, and again after discard declines in 2010. We estimate that North Sea discards declined by $48 \%$ from 509,840 tonnes in 1990 to 267,549 tonnes in 2010 . This waste had the potential to support 5.66 (95\% credible intervals: $3.33-9.74$ ) million seabirds in the 1990 s, declining by $39 \%$ to $3.45(1.98-5.78)$ million birds by 2010 . Our study reveals the potential for fishery discards to support very large scavenging seabird communities but also shows how this has declined over recent decades. Discard bans, like the European Union's Landing Obligation, may reduce inflated scavenger communities, but come against a backdrop of gradual declines potentially buffering deleterious impacts. More work is required to reduce uncertainty and to generate global estimates, but our study highlights the magnitude of scavenger communities potentially supported by discards and thus the importance of understanding the wider ecological consequences of dumping fisheries waste.
\end{abstract}

\section{KEYWORDS}

discards, energetics, fisheries, food requirements, scavengers, seabirds

\section{1 | INTRODUCTION}

Understanding fishery impacts is imperative for understanding marine ecology and conservation. The global marine fishing industry currently dumps $\sim 10$ million tonnes (10\%) of their annual catch (Zeller, Cashion, Palomares, \& Pauly, 2018), yet discarding is probably one of the least studied component of fishery impacts. Discarding peaked at 18.9 million tonnes in 1989 , but has since almost halved
(Zeller et al., 2018), and changes in policy, such as discard bans in the European Union (EU Landing Obligation), Norway, Chile and New Zealand, are likely to reduce discarding further (Real et al., 2018). Although bans are desirable for stock management, they may have unforeseen knock-on effects for the mammals, seabirds, fishes and crustaceans that scavenge on discharged biomass (Bicknell, Oro, Camphuysen, \& Votier, 2013; Heath, Cook, Cameron, Morris, \& Speirs, 2014; Oro, Genovart, Tavecchia, Fowler, \& Martínez-Abraín, 
2013). However, we are unable to understand fully the impact of changing discards because of knowledge gaps about the number/ biomass of scavengers supported, how this has changed over time, or might vary in the future (Heath et al., 2014; Real et al., 2018).

Seabirds are the best-studied consumers of fisheries waste (Oro et al., 2013). At least $52 \%$ of species feed on discards to some degree, and fisheries waste is the dominant dietary item in some populations (Bicknell et al., 2013; Oro et al., 2013). Discarding has shaped many aspects of seabird ecology, including their movements (Bartumeus et al., 2010; Bodey et al., 2014; Votier et al., 2010), demography (Bicknell et al., 2013; Oro et al., 2013), and community structure (Church, Furness, Tyler, Gilbert, \& Votier, 2019; Votier et al., 2004). However, there is still relatively little known about the number of seabirds that discards can support, how this has changed over time and what the likely consequences of changes in discard availability may be for seabird communities. A fuller understanding of the wider ecosystem-level impact of fisheries requires that we address this knowledge gap.

The North Sea is one of the world's largest discard-producing regions (Heath \& Cook, 2015; Zeller et al., 2018) and also supports an internationally important seabird assemblage (Garthe, Camphuysen, \& Furness, 1996; Paleczny, Hammill, Karpouzi, \& Pauly, 2015). This makes it an excellent system in which to estimate the number of scavengers that could be supported by discards. During peak production in the late 1980s and early 1990s, North Sea fisheries generated 500,000-900,000 tonnes of discards (Alverson, 1997; Camphuysen \& Garthe, 1997; Tasker et al., 2000). These were estimated to support $\sim 6$ million seabirds in 1990 by Garthe et al. (1996) in one of the only studies to attempt such a calculation. However, the model used to arrive at that figure did not account for the precision of its input variables; had that uncertainty been propagated, the final estimate could have been very imprecise, with $95 \%$ confidence intervals of 2.2 and 16.3 million birds (Stratoudakis, 1999). At the time, the largest source of variation in the model came from very poor estimates of discard production (Stratoudakis, 1999). More reliable discard data for the region have recently become available which show a steep decline in the overall quantity of fish discharged over the period 1978-2011 (Heath \& Cook, 2015). Moreover, catches have also shifted away from fish that are easy for seabirds to swallow ( 80\% roundfish) to less easily ingested fish ( $>50 \%$ flatfish) (Heath \& Cook, 2015), and the North Sea seabird community has also changed since the 1990s (Church et al., 2019; Mitchell, Newton, Ratcliffe, \& Dunn, 2004). A robust estimate-acknowledging the inevitable uncertainties and accounting for long-term changes in discarding practices-of the size and composition of the discard scavenging seabird community in the North Sea is therefore overdue.

Here, we combine data on seabird abundance, diet and energetic expenditure, together with fisheries discard rates and fish energy content into bioenergetics models to estimate the number of seabirds that could be supported by discards in the North Sea around the time of peak production in the early 1990s (hereafter the 1990 model) and following discard declines in the late 2000s (hereafter the 2010 model) (Figure 1). We implement our model in a Bayesian

\begin{tabular}{|l|l|}
\hline IINTRODUCTION & 1 \\
\hline METHODS & 2 \\
\hline 2.1. North Sea seabird abundance & 3 \\
\hline 2.2. Seabird energy requirements & 3 \\
\hline 2.3. Seabird diet composition & 5 \\
\hline 2.4. Energy available from discards & 5 \\
\hline 2.5. Energy from discards assimilated by seabirds & 7 \\
\hline 2.6. Number of seabirds supported & 7 \\
\hline 3 RESULTS & 8 \\
\hline 3.1 North Sea discard production & 8 \\
\hline 3.2 Number of seabirds supported by North Sea & 8 \\
\hline discards & 8 \\
\hline 3.3 Changes in scavenging seabird community sup- & 8 \\
\hline ported by discards & 11 \\
\hline 4 DISCUSSION & 9 \\
\hline 4.1 Estimates of discard production & 9 \\
\hline 4.2 Challenges in estimating the size of discard & 9 \\
\hline communities & 11 \\
\hline 4.3 Ecological implications of declining discards on & 10 \\
\hline seabird communities & 11 \\
\hline 4.4 Global context & \\
\hline 5 CONCLUSIONS & 11 \\
\hline ACKNOWLEDGEMENTS & \\
\hline DATA AVAILABILITY STATEMENT & \\
\hline REFERENCES & \\
\hline
\end{tabular}

framework, so that we can carry over input parameter uncertainty, and present our estimates split by species and by breeding and nonbreeding seasons. We also consider our work in the context of global fisheries so that a broader understanding of the size of scavenging communities might be achieved. Finally, we discuss the ecological implications of our results in light of potential changes in practise and policy around discarding-the least studied component of fisheries impacts.

\section{2 | METHODS}

We focussed on a scavenger community of eight regular discard consuming North Sea seabird species (see Table 1 for species names, Figure 2) (Garthe et al., 1996). We define "discards" as fish and invertebrates caught at sea, but subsequently discharged, and "offal" as the livers and intestines of marketable fish removed during sorting and cleaning, and subsequently thrown overboard (Garthe et al., 1996). For the purposes of our model, we assumed that both the availability of natural prey and discards were constant in space and time. We implemented our bioenergetics model in JAGS (v.4.3.0; Plummer, 2003), an open-source software for fitting Bayesian hierarchical models using Monte-Carlo Markov 
FIGURE 1 Schematic outlining the bioenergetic model used to estimate the number of seabirds in the North Sea supported by discards in 1990 and 2010

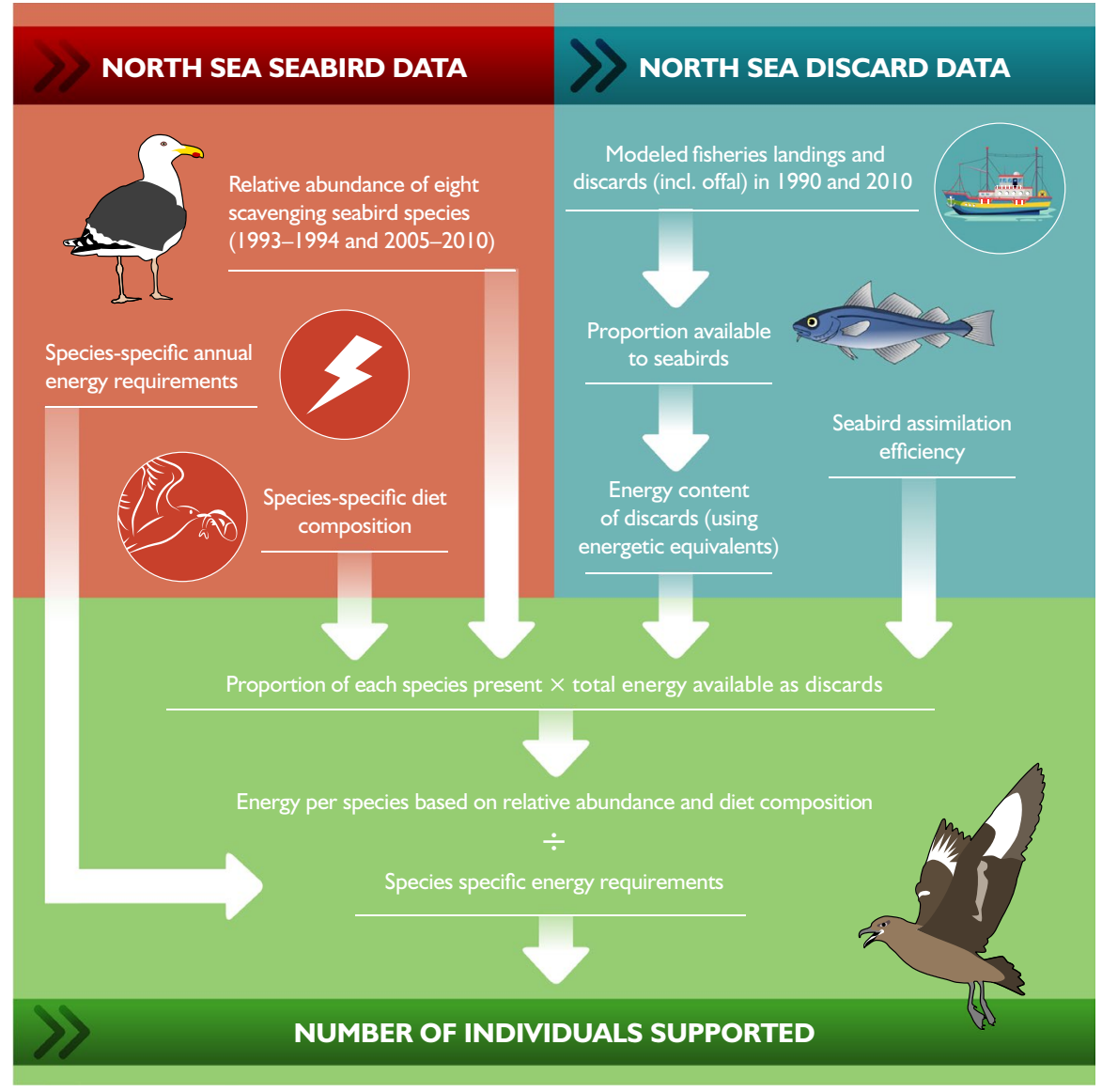

Chain (MCMC) simulation. We called JAGS via the "jagsUI" library (v. 1.4.9) for the open-source software R (v.3.2.3). Inference was based on three chains (iterations $=1,100,000$ samples, burnin $=100,000$, thinning $=10$ ). Convergence was checked visually and using Gelman-Rubin diagnostics (all $\hat{R}$ values $\leq 1.01$ ) (Brooks $\&$ Gelman, 1998). Unless specified, we present means $\pm 95 \%$ Bayesian credible intervals $(\mathrm{Cl})$.

\subsection{North Sea seabird abundance}

For our 1990 model, we used published estimates of the relative abundance (proportions) of the eight seabird species (s) derived from the European Seabirds at Sea (ESAS) database and the International Bottom Trawl Survey (IBTS) database (Camphuysen et al., 1995; Garthe et al., 1996). We used the mean from both studies from May to June and August to September 1994 as the estimates for the breeding abundance $\left(M_{B, S}\right)$ and the mean from both studies for surveys in January/February 1993 and October-November 1994 as the estimate for the non-breeding abundance $\left(M_{N, s}\right.$; Table 1). For our 2010 model, we calculated mean abundances using data in the ESAS database (v.5.0). Birds were counted by strip-transect during ship-based surveys in the North Sea (Camphuysen \& Garthe, 2004; Tasker, Jones, Dixon, $\&$ Blake, 1984). As coverage has been unequal over seasons and has decreased in recent years, the data from 2005 to 2010 were pooled to provide adequate coverage for ICES areas IVa, IVb and IVc and seasons, giving a total survey area of $23,266 \mathrm{~km}^{2}$. Speciesspecific correction factors were applied to account for birds that may have been overlooked (Stone et al., 1995). Abundances of all eight species were calculated separately for the three areas, and separately for a breeding (May to August) and a non-breeding period (September to April). Abundances were averaged over the three areas (to give geographic regions equal representation) and converted to relative abundance proportions (Table 1).

\section{2 | Seabird energy requirements}

For both the 1990 and 2010 model, we calculated species-specific annual energy requirements $\left(R_{\mathrm{A}, \mathrm{S}}\right)$ as:

$$
R_{A, S}=\left(F_{B, S} \times P_{B, S}\right)+\left(F_{N, S} \times P_{N, S}\right)
$$

where $F_{B, S}$ and $F_{N, s}$ are field metabolic rates $(F M R, k J / d)$ for breeding and non-breeding seabirds, respectively, and $P_{B, s}$ and $P_{N, s}$ are species-specific breeding and non-breeding periods (in days), respectively (Table 1 ). To estimate $F_{B, s}$ and $F_{N, s}$, we used a webbased Seabird FMR Calculator tool (https://ruthedunn.shinyapps. io/seabird_fmr_calculator) which uses a phylogenetically informed meta-analysis of seabird FMR during the breeding season (Dunn, 


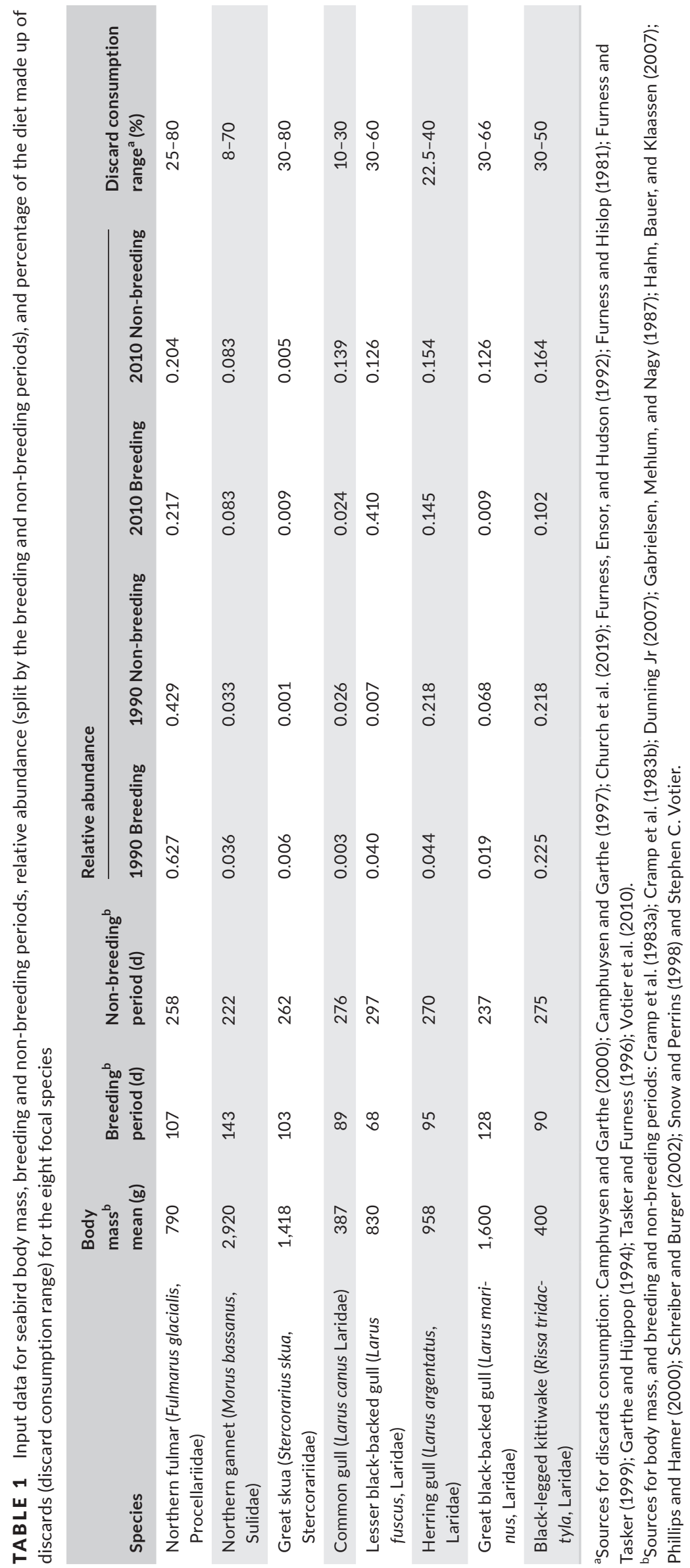



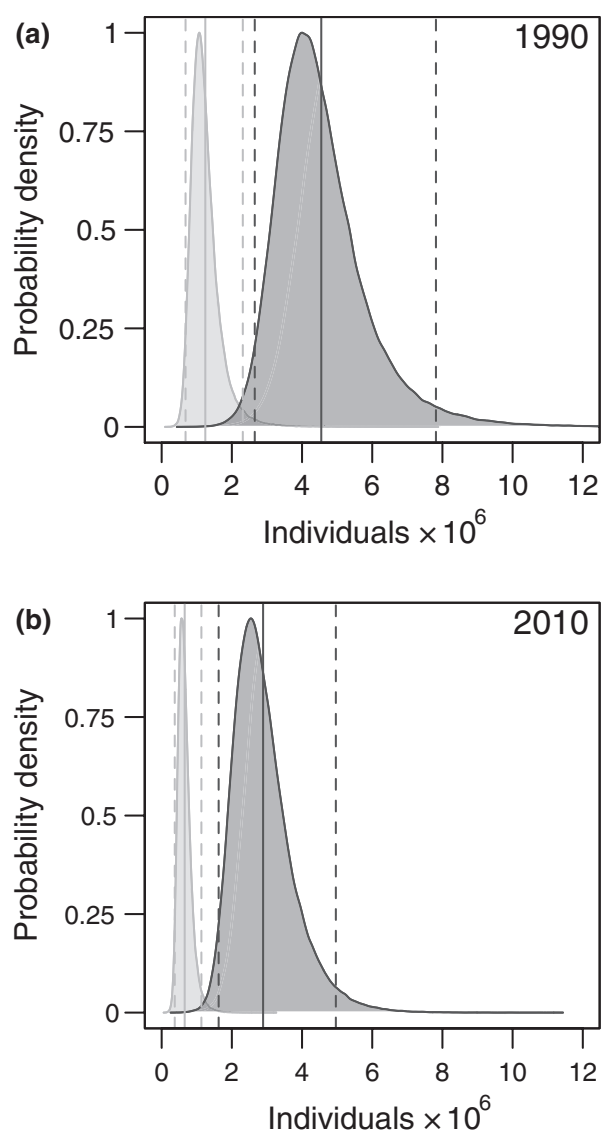

FIGURE 2 Posterior probability densities (polygons), means (solid line) and $95 \% \mathrm{Cl}$ (dashed lines) for the estimated number of seabirds consuming fishery discards in the North Sea during the breeding (light grey) and non-breeding seasons (dark grey) in (a) 1990 (b) 2010

White, \& Green, 2018). The tool requires inputs of species, body mass, colony latitude and breeding phase, and outputs an estimate of daily FMR with confidence intervals for each of three breeding phases: incubation, brood and crèche (post-guard) (Dunn et al., 2018). We used species-specific mean body masses (Table 1) and assumed a colony latitude of $55^{\circ} \mathrm{N}$ in each case. We then used the resulting estimate $((\bar{x}))$, lower $(L)$ and upper $(U)$ confidence intervals to estimate a standard deviation (SD) for each species $(s)$ and in each of the three breeding phases $(p)$ based on the central limit theorem:

$$
S D_{p, s}=\frac{\left(U_{p, s}-\bar{x}_{p, s}\right) / 1.96+\left(\bar{x}_{p, s}-L_{p, s}\right) / 1.96}{2}
$$

We then used these values to specify informative gamma priors (Figure S1). For $F_{N, s}$, we used the estimates of FMR during incubation to specify $\operatorname{Gamma}\left(\alpha_{N, s}, \beta_{N, s}\right)$, where $\alpha_{N, s}=$ the shape parameter $\left(\bar{x}_{p, s}^{2} / S D_{p, s}^{2}\right)$, and $\beta_{N, s}=$ the rate parameter $\left(\bar{x}_{p, s}^{2} / S D_{p, s}^{2}\right)$ and $p=$ incubation. For $F_{B, s}$, we combined all three breeding phase estimates by taking 999,999 random samples (sim) from a gamma distribution (using the "rgamma" function for R), with one third generated using the shape and rate from each breeding phase. We then extracted species-specific shape $\left(\alpha_{B, s}\right)$ and rate $\left(\beta_{B, s}\right)$ parameters for breeding, based on the mean $\left(\bar{x}_{\text {sim }}\right)$ and $S D\left(S D_{\text {sim }}\right)$, where $\alpha_{B, S}=\left(\bar{x}_{\text {sims }} / S D_{\text {sim }}\right)^{2}$ and $\beta_{B, s}=\bar{x}_{\text {sims }} / S D_{\text {sim }}^{2}$.

\section{3 | Seabird diet composition}

For both 1990 and 2010, we modeled the species-specific discard proportions in the diet $\left(\alpha_{s}\right)$ using 39 observations from 9 studies (ranges and sources shown in Table 1). We kept these values consistent for the two model runs because we could not find any specific diet studies for this period that reported a percentage of discards in the diet that fell outside of the range we used to capture the uncertainty in this parameter (Table 1; see Appendix S1 for details) and the one long-term diet study that collected across this period showed no evidence of a temporal trend in the proportion of great skua pellets containing discards (Church et al., 2019; Figure S2). Because there were between 3 and 8 observations for each species (Figure S3), we combined the data and used beta regression, with species as a random effect:

$$
\begin{gathered}
Y_{j} \sim \operatorname{Beta}\left(\varsigma_{j}, \rho_{j}\right), \\
\varsigma_{j}=\mu_{j} \tau_{j, s}, \\
\rho_{j}=\left(1-\mu_{j}\right) \tau_{j, s}, \\
\log \left(\tau_{j, s}\right) \sim \operatorname{Normal}\left(0,10^{-3}\right), \\
\mu_{j}=\theta_{s} X_{j}+b_{j, s}
\end{gathered}
$$

where $Y_{j}$ are the 39 observed proportions, $\theta_{s}$ is the coefficient estimate for a species-specific mean proportion, $b_{j, s}$ denotes a random effect accounting for repeat observations $(j)$ within species $(s)$, and $X_{j}$ is a vector denoting the species to which an observation belongs. For $\theta_{s}$, we specified a uniform prior bounded by the minimum and maximum observation in the data set: Uniform $(0.08,0.8)$ and used Normal $\left(0,1 / \sigma^{2}\right)$ for the hyper-prior associated with the random effect $\left(b_{j, s}\right)$, where the precision was $1 / \sigma^{2} \sim \operatorname{Gamma}\left(10^{-3}, 10^{-3}\right)$. Finally, the amount of its annual energy requirement that each species could obtain from discards $\left(D_{A, s}\right)$ was as follows:

$$
D_{\mathrm{A}, \mathrm{S}}=R_{\mathrm{A}, \mathrm{S}} \times \alpha_{\mathrm{S}}
$$

\subsection{Energy available from discards}

To calculate the energy available as discards, we used informative gamma priors which we generated by multiplying the modeled mean $( \pm 95 \% \mathrm{Cl})$ tonnage landed and discarded by mixed demersal fisheries in the North Sea in each of 1990 and 2010 (Heath \& Cook, 2015) by energetic equivalents for each discard type (Table 2) to obtain calorific values (Figures S4and S5). To estimate the tonnage of benthic invertebrates discarded, we incorporated the published range of 4-11 kg of benthic invertebrates discarded for every kg of sole (Solea solea, Soleidae) landed (Bergman, Fonds, De Groot, \& Van Santbrink, 


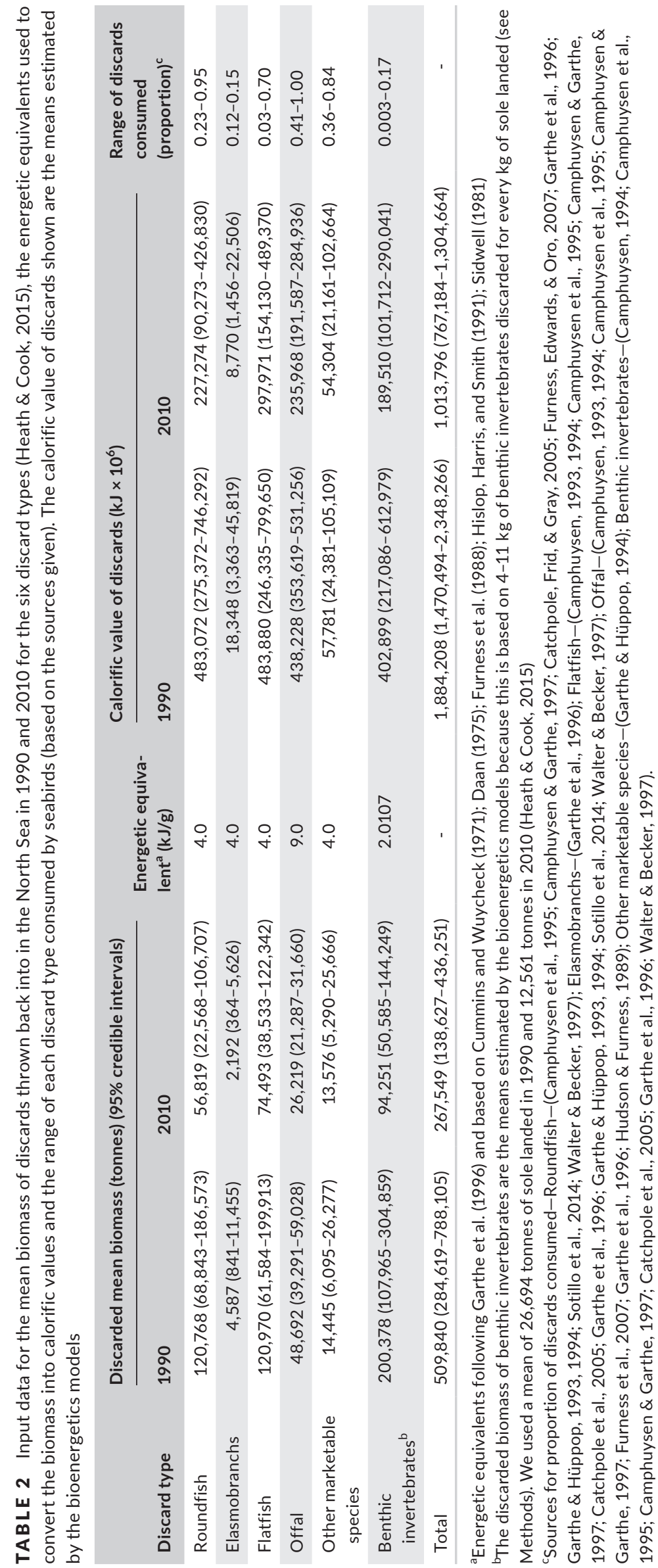


1996; Camphuysen et al., 1995; Fonds, 1991; Fonds, Verboom, \& Groeneveld, 1992) as a uniform prior in both models. Offal was assumed to make up $11 \%$ of roundfish landed mass, $6.5 \%$ for flatfish (Furness, Hudson, \& Ensor, 1988) and 2.35\% for other marketable species caught (Garthe et al., 1996). Because these values were reported without uncertainty, we assessed the sensitivity of our model to them by rerunning the 1990 model with the offal produced from roundfish (11\%), flatfish (6.5\%) and other marketable species $(2.35 \%)$ increased and decreased by $10 \%$, and by rerunning the 2010 model with the amount of offal discharged set to zero (see Supplementary Results in Appendix S1). We then used the resulting mean $(\bar{x})$, lower $(L)$ and upper $(U)$ 95\% confidence intervals to estimate a standard deviation (SD) for each discard type $(t)$ following equation 2 and used these values to specify informative gamma priors: $\operatorname{Gamma}\left(\delta_{t}, \varpi_{t}\right)$, where $\delta_{t}=$ the rate parameter $\left(\delta_{t}=\bar{x}_{t}^{2} / S D_{t}^{2}\right)$ and $\varpi_{t}=$ the shape parameter $\left(\varpi_{t}=\bar{x}_{t} / S D_{t}^{2}\right)$.

Seabirds do not always consume all available discards, and consumption rates vary by type (Camphuysen et al., 1995; Garthe et al., 1996). We therefore modeled the uncertainty in the proportion of the available discards that seabirds consume for each discard type (Figure S6) using 61 observed consumption rates from 12 field studies (see Table 2) for both 1990 and 2010. There were between 2 and 16 observations per discard type, so we combined the data and used beta regression, with discard type as a random effect. However, $100 \%$ of offal was eaten in one discard experiment (Garthe et al., 1996) and although 0 and 1 may be genuine outcomes, their logits are undefined (Smithson \& Verkuilen, 2006). One common solution is to transform the data $(Z)$ to a variable $(Z)$ in the open interval $(0,1)$ using a weighted average (Smithson \& Verkuilen, 2006):

$$
\dot{Z}=(Z(N-1)+k) / N
$$

where $N$ is the sample size and $k$ is a constant. The choice of $k$ is essentially arbitrary (Smithson \& Verkuilen, 2006), and we used 0.5092 (the mean of $Z$ ) as that minimized the overall error between $Z$ and $Z$ $\left(<7 \times 10^{-17}\right)$. Thus, the type-specific consumption rates $\left(c_{t}\right)$ were modeled as:

$$
\begin{gathered}
\dot{Z}_{j} \sim \operatorname{Beta}\left(\varsigma_{j}, \rho_{j}\right), \\
\varsigma_{j}=\mu_{j} \tau_{j, t}, \\
\rho_{j}=\left(1-\mu_{j}\right) \tau_{j, t}, \\
\log \left(\tau_{j, t}\right) \sim \operatorname{Normal}\left(0,10^{-3}\right), \\
\mu_{j}=c_{t} V_{j}+b_{j, t}
\end{gathered}
$$

where $Z_{j}$ are the 61 observed proportions transformed into the interval $(0,1), c_{t}$ is the coefficient estimate for a type-specific mean proportion, $b_{j, s}$ denotes a random effect accounting for repeat observations $(j)$ within type $(t)$ and $V_{j}$ is a vector denoting the discard type to which an observation belongs. For $c_{t}$, we specified a uniform prior: Uniform $(0,1)$ and used $\operatorname{Normal}\left(0,1 / \sigma^{2}\right)$ for the hyperprior associated with the random effect $\left(b_{j, t}\right)$, where the precision was $1 / \sigma^{2} \sim \operatorname{Gamma}\left(10^{-3}, 10^{-3}\right)$.

\section{5 | Energy from discards assimilated by seabirds}

The amount of energy animals assimilate varies according to food type. We used 45 data points from 14 studies on 22 seabird species consuming diets of various fish and invertebrate species to model the uncertainty in assimilation efficiency for all discard types (Figure S7) using beta regression. For both 1990 and 2010, the mean assimilation efficiency $\left(G_{\text {mod }}\right)$ was modeled as:

$$
\begin{gathered}
v_{j} \sim \operatorname{Beta}\left(\xi_{j}, \rho_{j}\right), \\
\xi_{j}=\eta_{j} \tau, \\
\rho_{j}=\left(1-\eta_{j}\right) \tau, \\
\log (\tau) \sim \operatorname{Normal}\left(0,10^{-3}\right), \\
\eta_{j}=G_{\text {mod }}
\end{gathered}
$$

where $v_{j}$ are the 45 observed assimilation efficiencies and $G_{\text {mod }}$ is the coefficient estimate for a mean assimilation efficiency, for which we specified an uninformative uniform prior: Uniform $(0,1)$.

The available energy from invertebrates $\left(G_{l}\right)$ was thus:

$$
A_{l}=\left(\left(W_{l} \times E_{l}\right) \times G_{\bmod }\right) \times C_{l}
$$

where $C_{l}$ is the beta distribution for the proportion of invertebrate discards consumed, $E_{l}$ is the gamma distribution for the energy available from invertebrate discards, $G_{\text {mod }}$ is the beta distribution for the modeled assimilation efficiency and $W_{1}$ is the uniform distribution Uniform $(4,11)$ for the conversion factor from landings of sole. For the five other discard types ( $t$; roundfish, flatfish, elasmobranchs, offal and other marketable species, Table 2 ) the available energy $\left(G_{t}\right)$ was defined as:

$$
G_{t}=\left(C_{t} \times E_{t}\right) \times G_{\bmod }
$$

where $C_{t}$ is the type-specific beta distribution for the proportion of discards consumed, $E_{t}$ is the gamma distribution for the energy available from each discard type and $G_{\text {mod }}$ is the beta distribution for the modeled assimilation efficiency. The total energy that can be assimilated from discards $(G)$ was thus:

$$
G=\sum_{t=1}^{5} G_{t}+G_{l}
$$

The annual total energy available to each seabird species $\left(E_{A, S}\right)$ was therefore:

$$
E_{\mathrm{A}, \mathrm{S}}=\left(\left(G \times P_{\mathrm{B}, \mathrm{S}}\right) \times M_{\mathrm{B}, \mathrm{S}}\right)+\left(\left(G \times P_{\mathrm{N}, \mathrm{S}}\right) \times M_{\mathrm{N}, \mathrm{S}}\right)
$$

where $L_{B, s}$ and $L_{N, s}$ are (respectively) the breeding and non-breeding season seabird abundances.

\subsection{Number of seabirds supported}

The number of seabirds supported by discards in each species $\left(T_{s}\right)$ was as follows:

$$
T_{s}=E_{A, S} / D_{A, S}
$$




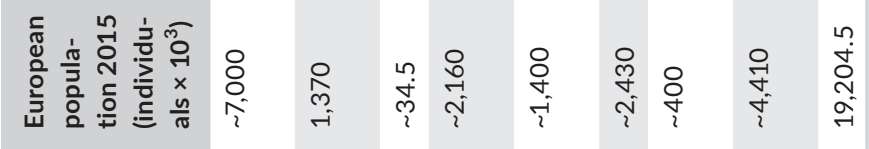

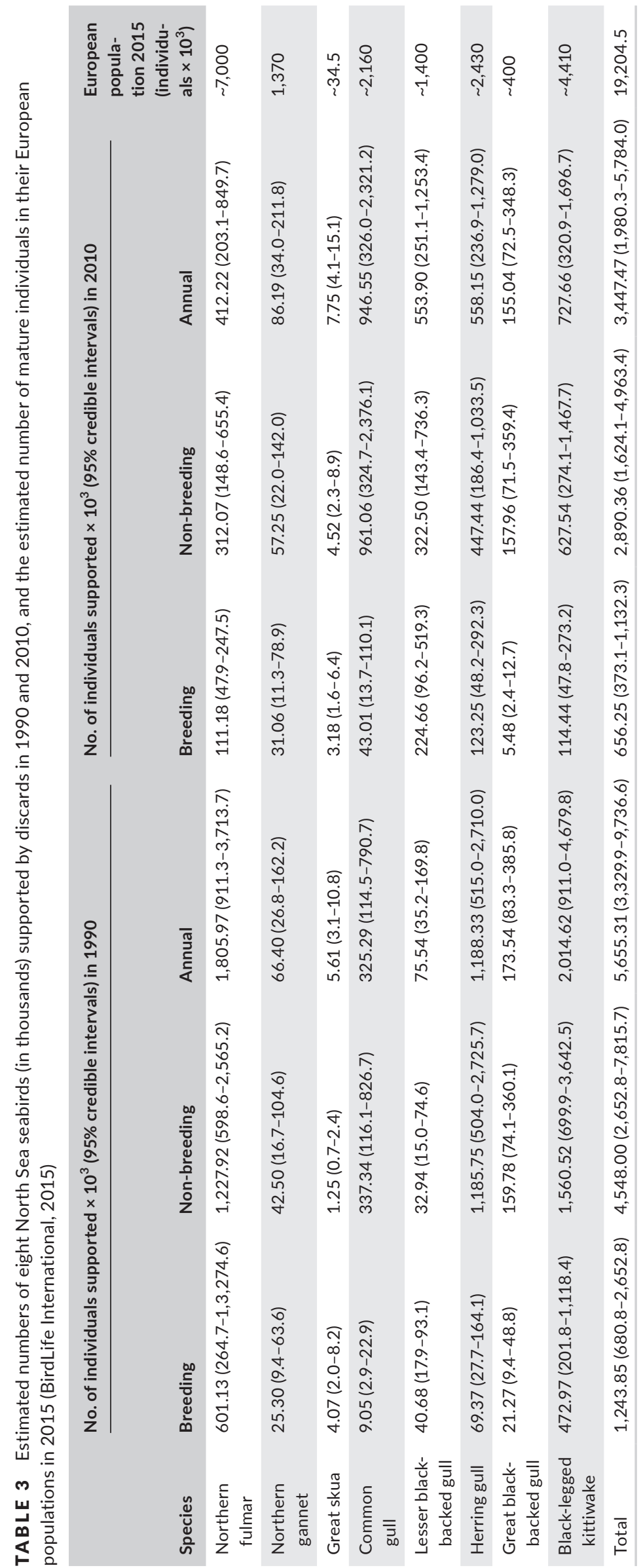

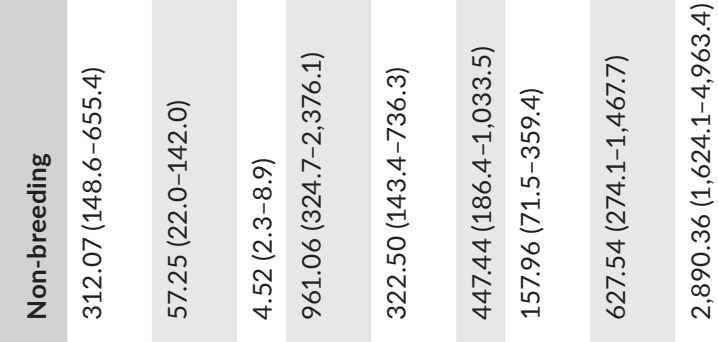

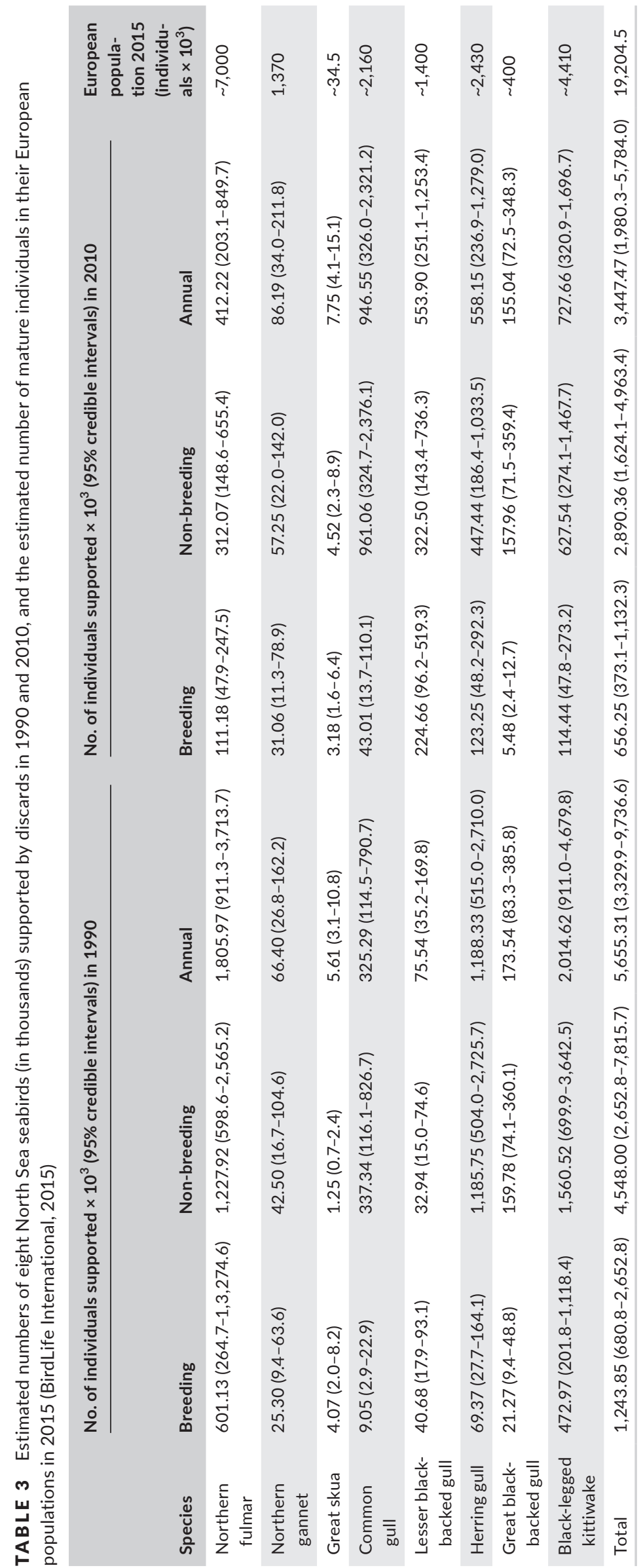

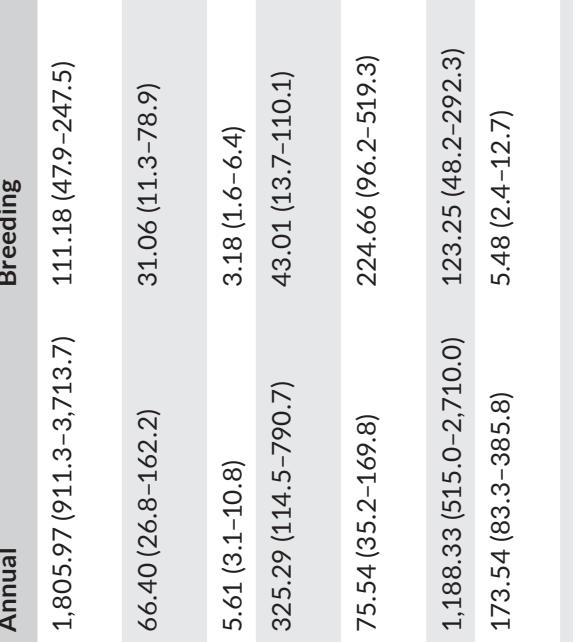


and the total number of seabirds supported by discards in the North Sea $(T)$ was as follows:

$$
T=\sum_{s=1}^{8} T_{s}
$$

To provide a sense of relative scale, we compare our outputs to species-specific estimates of the number of mature individuals in their European breeding populations (Table 3). We use the European breeding populations because individuals of at least some of our focal species move into, and winter in, the North Sea from other parts of Europe during their non-breeding seasons (Fort et al., 2012; Frederiksen et al., 2012; Garthe, Hallgrimsson, Montevecchi, Fifield, \& Furness, 2016).

\section{3 | RESULTS}

\subsection{North Sea discard production}

We estimate that North Sea mixed demersal fisheries generated $509,840(284,619-788,105)$ tonnes of discards in 1990 and this declined by $48 \%$ to 267,549 (138,627-436,251) tonnes in 2010 (Table 2). Roundfish, which are particularly important food for seabirds because they can be easily swallowed, declined by $52.9 \%$ (Table 2 ; from 120,768 to 56,819 tonnes). When taking account of the energetic content of different discard types, this represented 1,884 (1,4712,348 ) and 1,014 (767-1,305) billion $\mathrm{kJ}$ of biomass discarded from North Sea mixed demersal fisheries in 1990 and 2010, respectively.

\subsection{Number of seabirds supported by North Sea discards}

After accounting for assimilation efficiency and consumption rates in 1990, 720 (499-984) billion kJ were available to support an estimated $1.24(0.68-2.65)$ million birds during breeding and 4.55 (2.65-7.82) million during the non-breeding season (Figure 2A). In 2010, 385 (257-548) billion kJ of discards could be used, potentially supporting $656,255(373,084-1,132,250)$ birds during breeding and 2.89 (1.62-4.96) million individuals during the non-breeding season (Figure 2B). Combining the seasonal posteriors gave a total of 5.66 (3.33-9.74) million seabirds potentially supported in 1990 versus 3.45 (1.98-5.78) million individuals-or $39 \%$ fewer-able to consume fishery discards in the North Sea in 2010 (Figure 3A).

\subsection{Changes in scavenging seabird community supported by discards}

The largest declines in the number of birds supported were for northern fulmars and black-legged kittiwakes, and the largest increases were in the numbers of lesser black-backed gulls and common gulls potentially feeding on discards (Figure 3B). Although the overall number has approximately halved, the annual estimate for 2010 still represents $18 \%$ (Cl: 10-30\%) of these eight species' estimated European populations in 2015 (Table 3), with this percentage
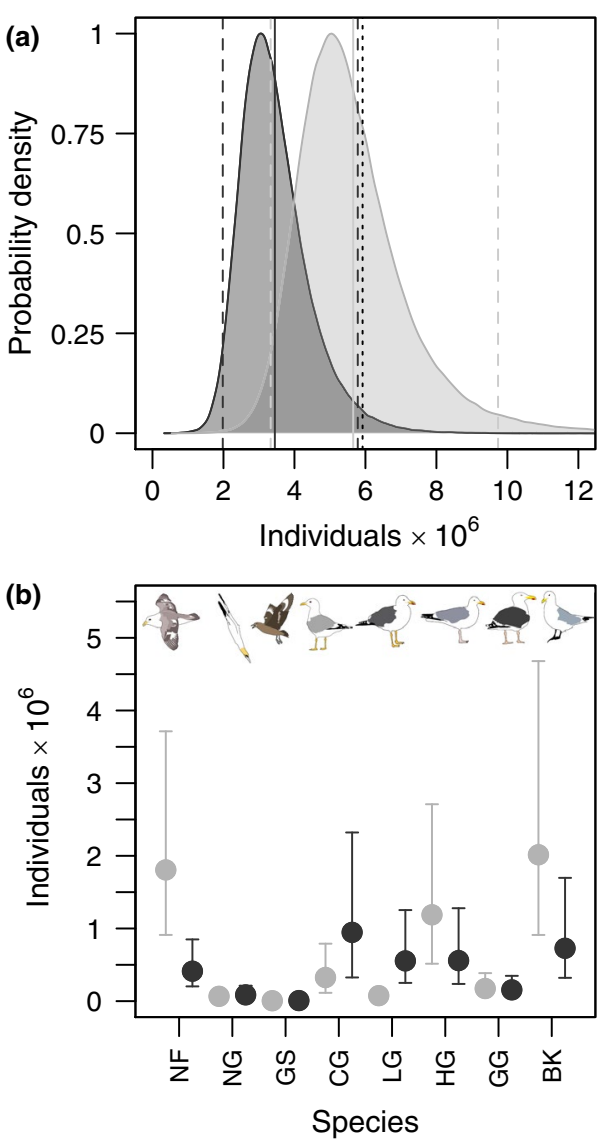

FIGURE 3 (a) Posterior probability density (polygon), mean (solid line) and $95 \% \mathrm{Cl}$ (dashed lines) for the total estimated number of seabirds consuming fishery discards in the North Sea in 1990 (light grey lines and polygon) and 2010 (dark grey lines and polygon). A previous estimate of 5.9 million individuals supported by discards in 1990 (Garthe et al., 1996) is also shown (black dotted line) and (b) Posterior means (circles) and 95\% Cl (whiskers) for the estimated number of individuals consuming discards in the North Sea in 1990 (light grey) and 2010 (dark grey) for the eight focal species: BK, black-legged kittiwake; CG, common gull; GG, great black-backed gull; GS, great skua; HG, herring gull; LG, lesser blackbacked gull; NF, northern fulmar; NG, northern gannet

being highest for common gulls at $44 \%$ (Cl: 15-108\%) and lowest for northern fulmars at 6\% (Cl: 3-12\%) (Table 3).

\section{DISCUSSION}

In this study, we estimate the number of seabirds that could be supported by discards in the North Sea, incorporating sources of uncertainty to include credible intervals around these values. We estimate that the change in discard composition (especially the decline in easily swallowed roundfish) and the $48 \%$ fall in total discard production in the North Sea from 1990 to 2010 (Table 2) led to a reduction of $\sim 2.2$ million seabirds (39\%) potentially supported by fishery waste (Figure 2). Wide credible intervals notwithstanding, the mean decline 
suggests substantial changes in the size and relative composition of the seabird scavenging assemblage. Below we discuss our approach, variation among species and seasons, the ecological implications in light of changes to fishing policy and the global implications of this study.

\section{1 | Estimates of discard production}

Our estimates of the biomass discarded into the North Sea were based on hind-cast estimates from landed weights and length distributions from scientific trawl surveys (Heath \& Cook, 2015). Catches in the scientific trawl surveys might differ substantially from commercial catches by other gear types, and there are likely to be other biases that we could not account for in our model. Nevertheless, these discard estimates appear to be robust. Our 1990s estimate of $509,840(284,619-788,105)$ tonnes is in keeping with earlier estimates, which placed the total amount of fish and benthic invertebrates at between 500,000 and 900,000 tonnes in the 1980s and 1990s (Alverson, 1997; Camphuysen \& Garthe, 1997; Tasker et al., 2000). Of that, 330,000 tonnes were considered to be demersal fish in 1991 (see Heath \& Cook, 2015) which compares well to our estimate for 1990 of 260,770 (137,363-424,218; Table 2) for all fish combined. Regardless, understanding how many scavengers are supported by fisheries discards will continue to depend on improved methods to estimate the biomass thrown back into the sea (Heath \& Cook, 2015; Stratoudakis, 1999).

\subsection{Challenges in estimating the size of discard communities}

Models of the type used here are limited by the quality and extent of data available for specific input parameters (Stratoudakis, 1999). Despite there being relatively good data on discards (Heath \& Cook, 2015) and the diet and abundance of scavenging seabirds available for the North Sea, our input parameters contained considerable uncertainty. When propagated through the model, this resulted in estimates with wide credible intervals (Figure 2), highlighting the challenges of generating precise estimates of the size of the scavenger community supported by discards, as well as the value of modeling these in a Bayesian framework.

Minimizing the uncertainty when estimating scavenger numbers supported by discards requires careful collection of data on scavenger ecology and biology. For example, estimates of the proportion of discards that get consumed by seabirds predominately come from a large-scale experimental programme undertaken in the North Sea in the 1990s in which potential prey were discarded at fixed intervals in time (Camphuysen et al., 1995; Garthe et al., 1996; Garthe \& Hüppop, 1998). The number of experimental results was small for some discards types (e.g. elasmobranchs), so the posterior uncertainty for this input parameter was influenced by our choice of prior to some extent (Figure S6). Also, these experiments reflected discharge rates from some gear types, such as those used in longline fisheries, but may overestimate consumption rates that occur following pulsed discharges from vessels engaged in demersal and pelagic trawling (Depestele, Rochet, Dorémus, Laffargue, \& Stienen, 2016). We are not aware of any comparable, large-scale discarding experiments that have been undertaken since (presumably for logistical and financial reasons), although smaller-scale and shorter-term experiments continue (Depestele et al., 2016; Sotillo, Depestele, Courtens, Vincx, \& Stienen, 2014). We recommend that such studies consider examining the influence of varying discharge rates on species-specific discard consumption.

Bioenergetics models are also sensitive to changes in diet composition and we therefore rely on accurate dietary data to parametrize models of this kind. Our data came from a range of methods, including analysis of chick regurgitates, pellets, isotopes and observations at sea, thus providing a robust estimate of seabird diet. However, there are uncertainties. For instance, there is strong intra-specific variation in discard consumption, with some individuals specializing on fisheries waste (Patrick et al., 2015; Tyson, Shamoun-Baranes, Van Loon, Camphuysen, \& Hintzen, 2015; Votier, Bearhop, Ratcliffe, Phillips, \& Furness, 2004; Votier et al., 2010). Moreover, the amount to which seabirds rely on discards likely changes with age (Votier, Bearhop, Fyfe, \& Furness, 2008), their annual cycle (Sotillo et al., 2014) and the availability of natural prey (Votier, Furness, et al., 2004). However, there remain little data available to parameterize a link between individual behaviour and population level effects of the kind relevant to our model (Patrick et al., 2015). Therefore, we urge that monitoring programmes incorporate data on seabird diet, at-sea distribution and abundance, across the full annual cycle and all components of the population to enable an effective ongoing assessment of the effects of changing discards on seabird populations.

\section{3 | Ecological implications of declining discards on seabird communities}

Shrinking stocks and discard bans will reduce fisheries waste, leading to less food for scavengers. Our study was able to quantify this change in the North Sea over a period of profound change. The revised estimate of 5.66 (3.33-9.74) million seabirds potentially supported in 1990 declined to 3.45 (1.98-5.78) in 2010. Other studies have suggested that the relative biomass of scavenging seabirds and marine mammals can be maintained under scenarios where discards from fisheries are reduced gradually (Fondo, Chaloupka, Heymans, \& Skilleter, 2015; Heath et al., 2014), perhaps because these groups are opportunistic and can quickly switch their diet away from fisheries waste (Tew Kai et al., 2013; Votier, Furness, et al., 2004). Abrupt changes associated with discard bans, like the EU's Landing Obligation, however, are expected to have substantial impacts on these species (Bicknell et al., 2013; Depestele et al., 2016; Fondo et al., 2015; Heath et al., 2014; Moutopoulos, Tsagarakis, \& Machias, 2018). In this context, it is noteworthy that our results suggest that a $39 \%$ decline in abundance of scavenging seabirds could already have occurred alongside a relatively gradual reduction in discards ( 48\%) over the two decades of our study, with some species affected more than others. 
The biggest declines in our model were in the numbers of northern fulmars ( 1.4 million or 77\%), black-legged kittiwakes ( 1.3 million or $64 \%)$, herring gulls $(630,000$ or $53 \%)$ and great blackbacked gulls $(\sim 18,500$ or $11 \%)$ supported (Table 1 , Figure 2$)$. These reductions represent significant percentages of the 2015 European population (Table 3 ) and of the numbers of these species thought to winter in the North Sea in the late-1980s and early-1990s; 1.9 million northern fulmars, 1 million black-legged kittiwakes, 900,000 herring gulls and $\sim 300,000$ great black-backed gulls (Skov, Durinck, Leopold, \& Tasker, 2007). These declines also coincide with population declines at some North Sea colonies in each of these species (BirdLife International, 2015; Camphuysen \& Gronert, 2012; Church et al., 2019; Foster, Swann, \& Furness, 2017). The reasons for these declines are not entirely clear, and may not necessarily be underpinned by changes in discards (Skov \& Durinck, 2001), though changes in herring gull numbers at some sites have been linked to declining discards (Foster et al., 2017). Some species may have been better able to buffer the gradual reduction in discards by feeding on alternative prey, being more aggressive competitors or by dispersing to novel habitats (Bicknell et al., 2013; Votier, Furness, et al., 2004). Prey switching could help to explain the increases in numbers of northern gannets $(30 \%)$ and great skuas (38\%) that could be supported (Table 1, Figure 2). Both species are dominant scavengers at fishing vessels (Oro et al., 2013) whose populations have remained relatively stable or increased during 1990 to 2010 (Hayhow et al., 2017). There were also sharp increases in the number of common (191\%) and lesser black-backed gulls (633\%) that could be supported, with our estimates suggesting that $>30 \%$ of the European population of both species are potentially using North Sea discards at some point during their annual cycle (Table 3). These large increases are likely because of changes in the distribution of these gulls (Oro et al., 2013) leading to higher relative abundance in the European Seabirds at Sea data used in our model.

Lastly, exactly how the ecological impacts of discard bans will manifest themselves remains unclear. They are likely to interact with climate-mediated declines in forage fish abundance (Church et al., 2019) and concurrent changes in policy that will reduce the accessibility of other anthropogenic subsidies, notably food waste at landfill sites (Real et al., 2017). Some scavengers will decline dramatically if they cannot find alternative prey sources (Heath et al., 2014), while other species may benefit from discard bans via reduced bycatch risk (Bicknell et al., 2013). Moreover, as the options that some species have relied on in the past disappear, trying to exploit alternative food sources could bring them into greater conflict with humans. For example, large gulls may be forced into inland breeding and feeding grounds (Bicknell et al., 2013; Osterback, Frechette, Hayes, Shaffer, \& Moore, 2015) where they are considered a nuisance, and great skua are likely to switch to predating other smaller seabird species (Votier, Furness, et al., 2004), some of which are now of conservation concern (Church et al., 2019). This could ultimately lead to a conundrum for management, as has occurred in southern Africa where great white pelicans (Pelecanus onocrotalus, Pelecanidae) and Cape fur seals
(Arctocephalus pusillus pusillus, Otariidae) are actively managed to stop them predating on four Endangered seabird species (David et al., 2003; Mwema, de Ponte Machado, \& Ryan, 2010). Finally, despite legislation, it is unclear how Landing Obligations will be implemented or enforced, highlighting further the need to quantify accurately discard production and its potential effect on scavengers.

\subsection{Global context}

While we focus on the North Sea, seabirds are attracted to feed on discards worldwide with associations reported from the southwest Atlantic (Granadeiro, Phillips, Brickle, \& Catry, 2011), western Mediterranean (Oro \& Ruiz, 1997), southern South America (Gonzalez-Zevallos \& Yorio, 2006), Baltic Sea (Garthe \& Scherp, 2003), northwest Atlantic (Montevecchi, 2002), southeast Atlantic (Crawford, Underhill, Raubenheimer, Dyer, \& Martin, 1992), Canary Current (Camphuysen \& van der Meer, 2005) and Australian waters (Svane, 2005). There are no global estimates of the number of seabirds that fisheries waste could support, but it is likely to be considerable given the global biomass of discards across all ocean basins. The historically high biomass of North Sea discards probably led to a particularly large scavenging community, making it inappropriate to scale our estimate up to other regions. Instead, a reliable global estimate would require not only detailed data on discards (Zeller et al., 2018) and seabird numbers (Paleczny et al., 2015), but also the composition of seabirds attending vessels and their diet. Such studies would be of particular significance given the large regional changes in discard production over time (Zeller et al., 2018).

\section{5 | CONCLUSIONS}

We estimate that North Sea discards can support $~ 3.45$ million seabirds per annum, but this declined by $39 \%$ from close to the period of peak discard production in the 1990s, indicating a shift away from a scavenger-dominated ecosystem. These findings are important in the context of global discard declines and bans, including the EU's Landing Obligation, as this gradual reduction may lessen any deleterious impacts of an abrupt drop in discards. Nevertheless, discards still have the potential to support large numbers of scavenging seabirds in the North Sea and the general lack of empirical data on the impacts of fishery discards at an ecosystem level makes it difficult to predict the real ecological consequences of the landing obligation. Further work is needed to monitor the response of seabird scavengers to changing fishery practices where discard bans are implemented and to quantify their numbers globally, particularly if we are serious about adopting an ecosystem-level approach to fisheries management. Data on global discard rates are available (Zeller et al., 2018), but information on seabird community composition, their diet and how this varies over time are also required in order to construct robust bioenergetics models. 


\section{ACKNOWLEDGEMENTS}

RBS was supported by the Leiden Conservation Foundation, Bristol Zoological Society, Zoological Society of San Diego and the Pew Fellows Program in Marine Conservation at The Pew Charitable Trusts. The views expressed are those of the authors and do not necessarily reflect the views of The Pew Charitable Trusts. We thank Robin M. Cook for posterior probabilities for the landings and discards from the mixed demersal fisheries in the North Sea. The authors have no conflicts of interest to report.

\section{ORCID}

Richard B. Sherley (iD https://orcid.org/0000-0001-7367-9315

Stephen C. Votier (ID https://orcid.org/0000-0002-0976-0167

\section{DATA AVAILABILITY STATEMENT}

The data used in the models are either in the Tables or appended at the end of the Supporting Information.

\section{REFERENCES}

Alverson, D. L. (1997). Global assessment of fisheries bycatch and discards: A summary overview. In E. K. Pikitch, D. D. Huppert, \& M. P. Sissenwine (Eds.), Global trends: Fisheries management, American fisheries society symposium 20 (pp. 115-125). Bethesda, MD: American Fisheries Society.

Bartumeus, F., Giuggioli, L., Louzao, M., Bretagnolle, V., Oro, D., \& Levin, S. A. (2010). Fishery discards impact on seabird movement patterns at regional scales. Current Biology, 20, 215-222. https://doi. org/10.1016/j.cub.2009.11.073

Bergman, M. J. N., Fonds, M., De Groot, S. J., \& Van Santbrink, J. (1996). Direct effects of beam trawl fishery on bottom fauna in the Southern North Sea. In J. Andersen, H. Karup, \& U. B. Nielsen (Eds.), Scientific Symposium on the North Sea, Quality Status Report 18-21 April 1994, Ebeltoft, Denmark (pp. 204-209). Copenhagen, Denmark: Danish Environmental Protection Agency.

Bicknell, A. W. J., Oro, D., Camphuysen, K. C. J., \& Votier, S. C. (2013). Potential consequences of discard reform for seabird communities. Journal of Applied Ecology, 50, 649-658. https://doi. org/10.1111/1365-2664.12072

BirdLife International (2015). European red list of birds. Retrieved from http://datazone.birdlife.org/info/euroredlist

Bodey, T. W., Jessopp, M. J., Votier, S. C., Gerritsen, H. D., Cleasby, I. R., Hamer, K. C., ... Bearhop, S. (2014). Seabird movement reveals the ecological footprint of fishing vessels. Current Biology, 24, R514-R515. https://doi.org/10.1016/j.cub.2014.04.041

Brooks, S. P., \& Gelman, A. (1998). General methods for monitoring convergence of iterative simulations. Journal of Computational and Graphical Statistics, 7, 434-455. https://doi.org/10.1080/10618 600.1998.10474787

Camphuysen, C. J. K. (1993). Fourageermogelijkheden voor zeevogels in de boomkorvisserij: Een verkennend onderzoek. Sula, 7, 81-104

Camphuysen, C. J. K. (1994). Flatfish selection by herring gulls Larus argentatus and lesser black-backed gulls Larus fuscus scavenging at commercial beamtrawlers in the southern North Sea. Netherlands Journal of Sea Research, 32, 91-98. https://doi. org/10.1016/0077-7579(94)90031-0
Camphuysen, C. J. K., Calvo, B., Durinck, J., Ensor, K., Follestad, A., Furness, R. W., \& Winter, C. J. N. (1995). Consumption of discards by seabirds in the North Sea. Final report to the European Commission, study contract BIOECO/93/10, NIOZ-Report 1995-5.

Camphuysen, C. J. K., \& Garthe, S. (1997). An evaluation of the distribution and scavenging habits of northern fulmars (Fulmarus glacialis) in the North Sea. ICES Journal of Marine Science, 54, 654-683. https:// doi.org/10.1006/jmsc.1997.0247

Camphuysen, C. J. K., \& Garthe, S. (2000). Seabirds and commercial fisheries: Population trends of piscivorous seabirds explained. In M. J. Kaiser, \& S. J. de Groot (Eds.), Effects of fishing on non-target species and habitats: Biological, conservation and socio-economic issues (pp.163-184). Oxford, UK: Blackwell Science.

Camphuysen, C. J. K., \& Garthe, S. (2004). Recording foraging seabirds at sea: Standardised recording and coding of foraging behaviour and multi-species foraging associations. Atlantic Seabirds, 6, 1-32.

Camphuysen, C. J. K., \& van der Meer, J. (2005). Wintering seabirds in West Africa: Foraging hotspots off Western Sahara and Mauritania driven by upwelling and fisheries. African Journal of Marine Science, 27, 427-437. https://doi.org/10.2989/18142 320509504101

Camphuysen, C. J., \& Gronert, A. (2012). Apparent Survival and Fecundity of Sympatric Lesser Black-Backed Gulls and Herring Gulls with Contrasting Population Trends. Ardea, 100, 113-122. https:// doi.org/10.5253/078.100.0202

Catchpole, T. L., Frid, C. L. J., \& Gray, T. S. (2005). Discards in North Sea fisheries: Causes, consequences and solutions. Marine Policy, 29, 421-430. https://doi.org/10.1016/j.marpol.2004.07.001

Church, G. E., Furness, R. W., Tyler, G., Gilbert, L., \& Votier, S. C. (2019) Change in the North Sea ecosystem from the 1970s to the 2010s: Great skua diets reflect changing forage fish, seabirds, and fisheries. ICES Journal of Marine Science, 76, 925-937. https://doi.org/10.1093/ icesjms/fsy 165

Cramp, S., Brooks, D. J., Collar, N. J., Dunn, E., Gillmor, R., Hollom, P. A. D., \& Wilson, M. G. (1983a). Handbook of the birds of Europe, the middle East and North Africa. The birds of the Western Palearctic. Volume I, Ostrich to Ducks. Oxford,UK: Oxford University Press.

Cramp, S., Brooks, D. J., Collar, N. J., Dunn, E., Gillmor, R., Hollom, P. A. D., \& Wilson, M. G. (1983b). Handbook of the birds of Europe, the middle East and North Africa. The birds of the Western Palearctic. Volume III, Waders to Gulls. Oxford, UK: Oxford University Press.

Crawford, R. J. M., Underhill, L. G., Raubenheimer, C. M., Dyer, B. M., \& Martin, J. (1992). Top predators in the Benguela ecosystem: Implications of their trophic position. South African Journal of Marine Science, 12, 675-687. https://doi.org/10.2989/02577 619209504732

Cummins, K. W., \& Wuycheck, J. C. (1971). Caloric equivalents for investigations in ecological energetics. Internationale Vereinigung Für Theoretische Und Angewandte Limnologie: Mitteilungen, 18, 1-158. https://doi.org/10.1080/05384680.1971.11903918

Daan, N. (1975). Consumption and production in North Sea cod, Gadus morhua: An assessment of the ecological status of the stock. Netherlands Journal of Sea Research, 9, 24-55. https://doi. org/10.1016/0077-7579(75)90021-6

David, J. H. M., Cury, P., Crawford, R. J. M., Randall, R. M., Underhill, L. G., \& Mëyer, M. A. (2003). Assessing conservation priorities in the Benguela ecosystem, South Africa: Analysing predation by seals on threatened seabirds. Biological Conservation, 114, 289-292. https:// doi.org/10.1016/S0006-3207(03)00018-1

Depestele, J., Rochet, M.-J., Dorémus, G., Laffargue, P., \& Stienen, E. W. M. (2016). Favorites and leftovers on the menu of scavenging seabirds: Modelling spatiotemporal variation in discard consumption. Canadian Journal of Fisheries and Aquatic Sciences, 73, 1446-1459. https://doi.org/10.1139/cjfas-2015-0326 
Dunn, R. E., White, C. R., \& Green, J. A. (2018). A model to estimate seabird field metabolic rates. Biology Letters, 14, 20180190. https://doi. org/10.1098/rsbl.2018.0190

Dunning, J. B. Jr (2007). CRC handbook of avian body masses, (2nd ed.). Boca Ranton, FL: Taylor \& Francis.

Fondo, E. N., Chaloupka, M., Heymans, J. J., \& Skilleter, G. A. (2015). Banning fisheries discards abruptly has a negative impact on the population dynamics of charismatic marine megafauna. PLoS ONE, 10, e0144543. https://doi.org/10.1371/journal.pone.0144543

Fonds, M. (1991). Measurements of catch composition and survival of benthic animals in beamtrawl fishery for sole in the southern North Sea. In: Effects of beam trawl fishery on the bottom fauna in relation to natural resources management and protection of the North Sea. EC Research contract MA 2-549, RIVO-DLO Umuiden. NIOZ, Texel. Texel: NIOZ.

Fonds, M., Verboom, B. L., \& Groeneveld, K. (1992). Catch composition and survival of fish and benthic invertebrates in commercial beam trawls for sole and plaice fishery in the southern North Sea. NIOZ Rapport, 16, 17-22

Fort, J., Pettex, E., Tremblay, Y., Lorentsen, S. H., Garthe, S., Votier, S., ... Grémillet, D. (2012). Meta-population evidence of oriented chain migration in northern gannets (Morus bassanus). Frontiers in Ecology and the Environment, 10, 237-242. https://doi. org/10.1890/110194

Foster, S., Swann, R. L., \& Furness, R. W. (2017). Can changes in fishery landings explain long-term population trends in gulls? Bird Study, 64, 90-97. https://doi.org/10.1080/00063657.2016.1274287

Frederiksen, M., Moe, B., Daunt, F., Phillips, R. A., Barrett, R. T., Bogdanova, M. I., ... Anker-Nilssen, T. (2012). Multicolony tracking reveals the winter distribution of a pelagic seabird on an ocean basin scale. Diversity and Distributions, 18, 530-542. https://doi. org/10.1111/j.1472-4642.2011.00864.x

Furness, R. W., Edwards, A. E., \& Oro, D. (2007). Influence of management practices and of scavenging seabirds on availability of fisheries discards to benthic scavengers. Marine Ecology Progress Series, 350, 235-244. https://doi.org/10.3354/meps07191

Furness, R. W., Ensor, K., \& Hudson, A. V. (1992). The use of fishery waste by gull populations around the British Isles. Ardea, 80, 105-113.

Furness, R. W., \& Hislop, J. G. (1981). Diets and feeding ecology of Great skuas Catharacta skua during the breeding season in Shetland. Journal of Zoology, 195, 1-23. https://doi.org/10.1111/j.1469-7998.1981. tb01890.x

Furness, R. W., Hudson, A. V., \& Ensor, K. (1988). Interactions between scavenging seabirds and commercial fisheries around the British Isles. In J. Burger (Ed.), Seabirds and other marine vertebrates: Competition, predation and other interactions (pp. 240-268). New York, NY: Columbia University Press.

Furness, R. W., \& Tasker, M. L. (1999). Diets of seabirds and consequences of changes in food supply. ICES Co-Operative Research Report, 232, 1-66

Gabrielsen, G. W., Mehlum, F., \& Nagy, K. A. (1987). Daily energy expenditure and energy utilization of free-ranging black-legged kittiwakes. Condor, 89, 126-132. https://doi.org/10.2307/1368766

Garthe, S., Camphuysen, C. J. K., \& Furness, R. W. (1996). Amounts of discards by commercial fisheries and their significance as food for seabirds in the North Sea. Marine Ecology Progress Series, 136, 1-11. https://doi.org/10.3354/meps136001

Garthe, S., Hallgrimsson, G. T., Montevecchi, W. A., Fifield, D., \& Furness, R. W. (2016). East or west? Migration routes and wintering sites of Northern Gannets Morus bassanus from south-eastern Iceland. Marine Biology, 163, 151. https://doi.org/10.1007/ s00227-016-2918-7

Garthe, S., \& Hüppop, O. (1993). Gulls and fulmars following ships and feeding on discards at night. Ornis Svecica, 3, 159-161

Garthe, S., \& Hüppop, O. (1994). Distribution of ship-following seabirds and their utilization of discards in the North Sea in summer. Marine
Ecology Progress Series, 106, 1-9. https://doi.org/10.3354/meps1 06001

Garthe, S., \& Hüppop, O. (1998). Possible biases in experiments evaluating the consumption of discards by seabirds in the North Sea. Marine Biology, 131, 735-741. https://doi.org/10.1007/s002270050364

Garthe, S., \& Scherp, B. (2003). Utilization of discards and offal from commercial fisheries by seabirds in the Baltic Sea. ICES Journal of Marine Science, 60, 980-989. https://doi.org/10.1016/ S1054-3139(03)00099-7

Gonzalez-Zevallos, D., \& Yorio, P. (2006). Seabird use of discards and incidental captures at the Argentine hake trawl fishery in the Golfo San Jorge, Argentina. Marine Ecology Progress Series, 316, 175-183. https ://doi.org/10.3354/meps316175

Granadeiro, J. P., Phillips, R. A., Brickle, P., \& Catry, P. (2011). Albatrosses following fishing vessels: How badly hooked are they on an easy meal? PLoS ONE, 6, e17467. https://doi.org/10.1371/journal.pone.0017467

Hahn, S., Bauer, S., \& Klaassen, M. (2007). Estimating the contribution of carnivorous waterbirds to nutrient loading in freshwater habitats. Freshwater Biology, 52, 2421-2433. https://doi. org/10.1111/j.1365-2427.2007.01838.x

Hayhow, D., Ausden, M., Bradbury, R., Burnell, D., Copeland, A., Crick, H., ... Williams, J. (2017). The state of the UK's birds 2017. Sandy, Bedfordshire: The RSPB, BTO, WWT, DEFRA, JNCC, NE and NRW.

Heath, M. R., \& Cook, R. M. (2015). Hind-Casting the Quantity and Composition of Discards by Mixed Demersal Fisheries in the North Sea. PLoS ONE, 10, e0117078. https://doi.org/10.1371/journ al.pone. 0117078

Heath, M. R., Cook, R. M., Cameron, A. I., Morris, D. J., \& Speirs, D. C. (2014). Cascading ecological effects of eliminating fishery discards. Nature Communications, 5, 3893. https://doi.org/10.1038/ncomms4893

Hislop, J. R. G., Harris, M. P., \& Smith, J. G. M. (1991). Variation in the calorific value and total energy content of the lesser sandeel (Ammodytes marinus) and other fish preyed on by seabirds. Journal of Zoology, 224, 501-517. https://doi.org/10.1111/j.1469-7998.1991.tb06039.x

Hudson, A. V., \& Furness, R. W. (1989). The behaviour of seabirds foraging at fishing boats around Shetland. Ibis, 131, 225-237. https://doi. org/10.1111/j.1474-919X.1989.tb02765.X

Mitchell, P. I., Newton, S. F., Ratcliffe, N., \& Dunn, T. E. (2004). Seabird populations of Britain and Ireland. London, UK: T \& AD Poyser.

Montevecchi, W. A. (2002). Interactions between fisheries and seabirds. In E. A. Schreiber, \& J. Burger (Eds.), Biology of marine birds (pp. 527557). Boca Ranton, FL: CRC Press.

Moutopoulos, D. K., Tsagarakis, K., \& Machias, A. (2018). Assessing ecological and fisheries implications of the EU landing obligation in Eastern Mediterranean. Journal of Sea Research, 141, 99-111. https:// doi.org/10.1016/j.seares.2018.08.006

Mwema, M. M., de Ponte Machado, M., \& Ryan, P. G. (2010). Breeding seabirds at Dassen Island, South Africa: Chances of surviving great white pelican predation. Endangered Species Research, 9, 125-131. https://doi.org/10.3354/esr00243

Oro, D., Genovart, M., Tavecchia, G., Fowler, M. S., \& Martínez-Abraín, A. (2013). Ecological and evolutionary implications of food subsidies from humans. Ecology Letters, 16, 1501-1514. https://doi. org/10.1111/ele.12187

Oro, D., \& Ruiz, X. (1997). Exploitation of trawler discards by breeding seabirds in the north-western Mediterranean: Differences between the Ebro Delta and the Balearic Islands areas. ICES Journal of Marine Science, 54, 695-707. https://doi.org/10.1006/jmsc.1997.0246

Osterback, A.-M., Frechette, D. M., Hayes, S. A., Shaffer, S. A., \& Moore, J. W. (2015). Long-term shifts in anthropogenic subsidies to gulls and implications for an imperilled fish. Biological Conservation, 191, 606613. https://doi.org/10.1016/j.biocon.2015.07.038

Paleczny, M., Hammill, E., Karpouzi, V., \& Pauly, D. (2015). Population trend of the world's monitored seabirds, 1950-2010. PLoS ONE, 10(6), e0129342. https://doi.org/10.1371/journal.pone.0129342 
Patrick, S. C., Bearhop, S., Bodey, T. W., Grecian, W. J., Hamer, K. C., Lee, J., \& Votier, S. C. (2015). Individual seabirds show consistent foraging strategies in response to predictable fisheries discards. Journal of Avian Biology, 46, 431-440. https://doi.org/10.1111/jav.00660

Phillips, R. A., \& Hamer, K. C. (2000). Growth and provisioning strategies of Northern Fulmars Fulmarus glacialis. Ibis, 142, 435-445. https:// doi.org/10.1111/j.1474-919X.2000.tb04440.x

Plummer, M. (2003). JAGS: A Program for Analysis of Bayesian Graphical Models Using Gibbs Sampling. In K. Hornik, F. Leisch, \& A. Zeileis (Eds.), Proceedings of the Third International Workshop on Distributed Statistical Computing (DSC 2003). Vienna, Austria. ISSN 1609-395X. https://www.ci.tuwien.ac.at/Conferences/DSC-2003/Proceedings/ Plummer.pdf

Real, E., Oro, D., Martínez-Abraín, A., Igual, J. M., Bertolero, A., Bosch, M., \& Tavecchia, G. (2017). Predictable anthropogenic subsidies, density-dependence and socio-economic factors influence breeding investment in a generalist seabird. Journal of Avian Biology, 48, 1462-1470. https://doi.org/10.1111/jav.01454

Real, E., Tavecchia, G., Genovart, M., Sanz-Aguilar, A., Payo-Payo, A., \& Oro, D. (2018). Discard-ban policies can help improve our understanding of the ecological role of food availability to seabirds. Scientia Marina, 82, S115-S120. https://doi.org/10.3989/scimar.04746.10A

Schreiber, E. A., \& Burger, J. (2002). Biology of marine birds. Boca Ranton, FL: CRC Press.

Sidwell, V. D. (1981). Chemical and nutritional composition of finfishes, whales, crustaceans, mollusks and their products (p. 432). Charleston, SC: NOAA Technical Memorandum NMFS F/SEC-11.

Skov, H., \& Durinck, J. (2001). Seabird attraction to fishing vessels is a local process. Marine Ecology Progress Series, 214, 289-298. https:// doi.org/10.3354/meps214289

Skov, H., Durinck, J., Leopold, M. F., \& Tasker, M. L. (2007). A quantitative method for evaluating the importance of marine areas for conservation of birds. Biological Conservation, 136, 362-371. https://doi. org/10.1016/j.biocon.2006.12.016

Smithson, M., \& Verkuilen, J. (2006). A better lemon squeezer? Maximum-likelihood regression with beta-distributed dependent variables. Psychological Methods, 11, 54-71. https://doi. org/10.1037/1082-989X.11.1.54

Snow, D. W., \& Perrins, C. M. (1998). The birds of the western palearctic (Concise Ed) Vol. 1. Oxford, UK: Oxford University Press.

Sotillo, A., Depestele, J., Courtens, W., Vincx, M., \& Stienen, E. W. M. (2014). Consumption of Discards by Herring Gulls Larus argentatus and Lesser Black-Backed Gulls Larus fuscus off the Belgian Coast in the Breeding Season. Ardea, 102, 195-206. https://doi.org/10.5253/ arde.v102i2.a9

Stone, C., Webb, A., Barton, C., Ratcliffe, N., Reed, T., Tasker, M. L., ... Pienkowski, M. (1995). An atlas of seabird distribution in north-west European waters. Peterborough, UK: Joint Nature Conservation Committee.

Stratoudakis, Y. (1999). Recommendations for improving the estimation of the number of seabirds potentially sustained by fisheries discards. Marine Ecology Progress Series, 176, 307-309 https://doi. org/10.3354/meps176307

Svane, I. (2005). Occurrence of dolphins and seabirds and their consumption of by-catch during prawn trawling in Spencer Gulf, South Australia. Fisheries Research, 76, 317-327. https://doi.org/10.1016/j. fishres.2005.07.012

Tasker, M. L., Camphuysen, C. J. K., Cooper, J., Garthe, S., Montevecchi, W. A., \& Blaber, S. J. M. (2000). The impacts of fishing on marine birds. ICES Journal of Marine Science, 57, 531-547. https://doi.org/10.1006/ jmsc.2000.00714
Tasker, M. L., \& Furness, R. W. (1996). Estimation of food consumption by seabirds in the North Sea. ICES Co-Operative Research Report, 216, 6-42

Tasker, M. L., Jones, P. H., Dixon, T., \& Blake, B. F. (1984). Counting seabirds at sea from ships: A review of methods employed and a suggestion for a standardized approach. Auk, 101, 567-577. https://doi. org/10.1093/auk/101.3.567

Tew Kai, E., Benhamou, S., van der Lingen, C. D., Coetzee, J. C., Pichegru, L., Ryan, P. G., \& Grémillet, D. (2013). Are Cape gannets dependent upon fishery waste? A multi-scale analysis using seabird GPS-tracking, hydro-acoustic surveys of pelagic fish and vessel monitoring systems. Journal of Applied Ecology, 50, 659-670. https://doi. org/10.1111/1365-2664.12086

Tyson, C., Shamoun-Baranes, J., Van Loon, E. E., Camphuysen, C. J. K., \& Hintzen, N. T. (2015). Individual specialization on fishery discards by lesser black-backed gulls (Larus fuscus). ICES Journal of Marine Science, 72, 1882-1891. https://doi.org/10.1093/icesjms/ fsv021

Votier, S. C., Bearhop, S., Fyfe, R., \& Furness, R. W. (2008). Temporal and spatial variation in the diet of a marine top predator - links with commercial fisheries. Marine Ecology Progress Series, 367, 223-232. https ://doi.org/10.3354/meps07621

Votier, S. C., Bearhop, S., Ratcliffe, N., Phillips, R. A., \& Furness, R. W. (2004). Predation by great skuas at a large Shetland seabird colony. Journal of Applied Ecology, 41, 1117-1128. https://doi. org/10.1111/j.0021-8901.2004.00974.x

Votier, S. C., Bearhop, S., Witt, M. J., Inger, R., Thompson, D., \& Newton, J. (2010). Individual responses of seabirds to commercial fisheries revealed using GPS tracking, stable isotopes and vessel monitoring systems. Journal of Applied Ecology, 47, 487-497. https://doi. org/10.1111/j.1365-2664.2010.01790.x

Votier, S. C., Furness, R. W., Bearhop, S., Crane, J. E., Caldow, R. W. G., Catry, P., ... Thompson, D. R. (2004). Changes in fisheries discard rates and seabird communities. Nature, 427, 727-730. https://doi. org/10.1038/nature02251.1

Walter, U., \& Becker, P. H. (1997). Occurrence and consumption of seabirds scavenging on shrimp trawler discards in the Wadden Sea. ICES Journal of Marine Science, 54, 684-694. https://doi.org/10.1006/ jmsc.1997.0239

Zeller, D., Cashion, T., Palomares, M., \& Pauly, D. (2018). Global marine fisheries discards: A synthesis of reconstructed data. Fish and Fisheries, 19, 30-39. https://doi.org/10.1111/faf.12233

\section{SUPPORTING INFORMATION}

Additional supporting information may be found online in the Supporting Information section.

How to cite this article: Sherley RB, Ladd-Jones H, Garthe S, Stevenson O, Votier SC. Scavenger communities and fisheries waste: North Sea discards support 3 million seabirds, 2 million fewer than in 1990. Fish Fish. 2019;00:1-14. https:// doi.org/10.1111/faf.12422 